Jurnal Ilmu Komunikasi UHO : Jurnal Penelitian Kajian Ilmu Komunikasi dan Informasi.

Volume 7, No. 1, Januari 2022, hlm 79-91

\title{
PEMANFAATAN MEDIA SOSIAL SEBAGAI PENDUKUNG MAHASISWA PENDIDIKAN TINGGI JARAK JAUH
}

\author{
Arifah Bintarti, Djoko Rahardjo, \\ Universitas Terbuka \\ Jalan Cabe Raya, Pamulang, Tangerang Selatan, Indonesia
}

\begin{abstract}
ABSTRAK
Pandemi Covid-19 berdampak besar pada berbagai sektor, salah satunya proses pembelajaran di perguruan tinggi jarak jauh. Tutorial online merupakan layanan pembelajaran yang dimanfaatkan oleh Universitas Terbuka. Selama pandemi, hampir semua orang mengakses internet sehingga kinerja teknologi dalam tutorial online menjadi lebih rendah. Kuantitas mahasiswa dalam mengikuti tutorial online cenderung meningkat namun kualitas aktivitas mahasiswa dalam mengakses tutorial belum optimal. Penelitian ini akan mengidentifikasi beberapa faktor penyebab belum optimalnya kualitas dalam mengakses tutorial online. Menggunakan metode kuantitatif dan kualitatif berupa wawancara, dengan sampel sebanyak 118 responden. Hasil penelitian menunjukkan bahwa siswa membutuhkan media sosial untuk meningkatkan proses belajar mereka dalam tutorial online. Media Sosial akan digunakan sebagai media tambahan untuk berkomunikasi dalam pelaksanaan tutorial online.
\end{abstract}

Kata-kata Kunci: pendidikan tinggi jarak jauh; media sosial; tutorial online 
Jurnal Ilmu Komunikasi UHO : Jurnal Penelitian Kajian Ilmu Komunikasi dan Informasi.

Volume 7, No. 1, Januari 2022, hlm 79-91

\title{
UTILIZATION OF SOCIAL MEDIA AS LEARNING SUPPORT FOR DISTANCE HIGHER EDUCATION STUDENTS
}

\begin{abstract}
The Covid-19 pandemic has had a major impact on various sectors, one of which is learning process in distance higher education. Online tutorial is a learning service utilized by Universitas Terbuka. During the pandemic, almost everyone accesses the internet so that the technological performance in the online tutorial became lower. The quantity of students in following online tutorials tends to increase but the quality of student activity in accessing tutorials is not optimal. This study will identify several factors that cause not optimal quality in accessing online tutorials. Using quantitative and qualitative methods in the form of interviews, with the sample of 118 respondents. The results show that student need social media to enhance their learning process in online tutorial. Social Media will be used as an additional medium to communicate in the implementation of online tutorials.
\end{abstract}

Keywords: distance higher education; social media; online tutorial. 
Jurnal Ilmu Komunikasi UHO : Jurnal Penelitian Kajian Ilmu Komunikasi dan Informasi.

Volume 7, No. 1, Januari 2022, hlm 79-91

\section{PENDAHULUAN}

Pandemi Covid-19 telah membawa perubahan yang luar biasa, termasuk dalam bisnis pendidikan. Seolah-olah semua jenjang pendidikan 'dipaksa' bertransformasi untuk beradaptasi secara tiba-tiba dan drastis ke belajar dari rumah melalui media online. Kondisi ini tentu bukan hal yang mudah karena masyarakat belum siap menghadapinya. Permasalahan dalam pendidikan adalah proses pembelajaran yang belum merata, baik standar maupun kualitas hasil belajar yang diinginkan.

Sejak saat itu, Universitas Terbuka telah menyediakan layanan pembelajaran dalam sistem manajemen pembelajaran (LMS), Moodle, sebagai media bagi mahasiswa untuk melakukan proses belajar mereka. Namun, beberapa siswa yang tinggal dibeberapa lokasi tidak dapat mengakses layanan tersebut secara optimal sehingga tingkat partisipasi dalam LMS cenderung lebih rendah. Dimasa pandemi, hampir semua orang mengakses internet, membuat kinerja internet dalam mengakses LMS itu sendiri turun. Pada kenyataannya kuantitas mahasiswa yang mengikuti tutorial online cenderung meningkat, namun kualitas partisipasi mahasiswa dalam mengakses tutorial belumlah cukup. Kurang optimalnya partisipasi mahasiswa dalam mengakses tutorial online diduga karena kurangnya motivasi mahasiswa dalam mengakses tutorial online. Tingginya penggunaan media sosial di kalangan mahasiswa dapat dijadikan sebagai sarana penunjang aktivitas mahasiswa dan partisipasi mahasiswa dalam tutorial online.

Media sosial semakin dikenal beberapa tahun setelah keberadaannya. Media sosial pada umumnya merupakan media untuk bersosialisasi dalam proses komunikasi. Media sosial kini telah merambah ke ruang rapat organisasi bisnis dan, seperti halnya internet (Icha \& Edwin, 2016). Meskipun media sosial merupakan fenomena baru, namun terbukti praktis atau bahkan lebih efektif daripada pemasaran tradisional.

Sedangkan menurut Kwaghga, Okike, and Ramatu (2019) media sosial merupakan metode pengajaran yang krusial dan tidak dapat disalahgunakan. Pada saat yang sama, literasi komputer dianggap sebagai bagian mendasar dari keterampilan profesional. Pustakawan yang melek komputer lebih produktif dan efisien dalam bekerja dibandingkan dengan yang tidak melek komputer (Angeline, 2019).

Dengan perkembangan pemanfaatan media sosial terutama dalam bidang pendidikan tinggi jarak jauh yang begitu pesatnya, perlu kiranya mengetahui sejauh mana hal itu 
Jurnal Ilmu Komunikasi UHO : Jurnal Penelitian Kajian Ilmu Komunikasi dan Informasi.

Volume 7, No. 1, Januari 2022, hlm 79-91

mendukung proses pembelajaran mahasiswa. Penelitian ini bertujuan untuk mengidentifikasi beberapa faktor bagaimana media sosial dapat mendukung mahasiswa belajar melalui tutorial online.

Sejak merebak pada Januari 2020, COVID-19 telah menyebar dengan cepat ke seluruh dunia dan telah menjadi pandemi global. Platform media sosial telah diakui sebagai alat penting untuk praktik promosi kesehatan dalam kesehatan masyarakat, dan penggunaan media sosial tersebar luas di kalangan masyarakat. Media sosial adalah alat yang efektif untuk mempromosikan perilaku pencegahan COVID-19 di kalangan masyarakat (Li \& Liu, 2020).

Pesatnya wabah COVID-19 telah membuka berbagai masalah di platform media sosial di kalangan siswa sekolah. Penelitian yang dilakukan oleh Radwan, Radwan, and Radwan (2020) ini bertujuan untuk mengetahui bagaimana media sosial mempengaruhi penyebaran kepanikan tentang COVID-19 di kalangan siswa sekolah dasar dan menengah di Jalur Gaza, Palestina. Populasi anak merupakan kelompok yang paling rentan terpapar faktor risiko lingkungan. Perguruan tinggi harus membekali mahasiswa dengan sikap, pengetahuan, dan keterampilan untuk menanggapi ini dengan menggunakan blended learning. (Alvarez-Garcia et al., 2019). Bahkan, menurut model kompensasi dari aktivitas yang berhubungan dengan Internet, lingkungan online dapat digunakan untuk menghilangkan perasaan negatif yang disebabkan oleh keadaan hidup yang menyedihkan, meskipun mereka berpotensi mengarah pada hasil negatif. Boursier, Gioia, Musetti, and Schimmenti (2020) menemukan bukti bahwa perasaan kesepian memprediksi penggunaan media sosial yang berlebihan dan kecemasan, dengan penggunaan media sosial yang berlebihan juga meningkatkan tingkat kecemasan. Namun, akses yang difasilitasi dan diperluas ke media sosial selama pandemi COVID-19 berisiko semakin meningkatkan kecemasan, menghasilkan lingkaran setan yang dalam beberapa kasus mungkin memerlukan perhatian klinis.

Berg, Forest, and Stenseng (2020) menguji apakah intervensi media sosial dapat mempromosikan hasrat yang harmonis dan emosi positif yang terkait dengan aktivitas olahraga. Intervensi tidak memprediksi perubahan gairah untuk aktivitas. Namun, intervensi memprediksi hasil emosional yang lebih positif dari aktivitas tersebut, secara statistik mengendalikan emosi yang dilaporkan pada awal dan emosi negatif yang dilaporkan pada tindak lanjut. Hasilnya menunjukkan bahwa platform digital mungkin relevan dalam 
Jurnal Ilmu Komunikasi UHO : Jurnal Penelitian Kajian Ilmu Komunikasi dan Informasi.

Volume 7, No. 1, Januari 2022, hlm 79-91

mempromosikan lebih banyak aktivitas fisik pada populasi, melalui fasilitasi lebih banyak emosi positif yang terkait dengan olahraga.

Sementara itu menurut Gupta and Bashir (2018), era digital saat ini telah menyebabkan lonjakan penggunaan Media Sosial di dunia akademis. Luasnya penggunaan platform media sosial di berbagai daerah ditentukan oleh faktor sosial, ekonomi, agama, politik, budaya, dan etnis, yang dapat membatasi partisipasi. Ini juga berfokus pada keterampilan linguistik penduduk dan keinginan mereka untuk terlibat dalam diskusi global.

Hal lain diungkapkan Bedford (2019) bahwa komunitas pembelajaran profesional telah digunakan di pendidikan tinggi untuk menyediakan platform bagi anggota fakultas untuk mendiskusikan tantangan dan membangun keterampilan profesional. Studi ini mengkonfirmasi penelitian sebelumnya tentang manfaat komunitas tersebut untuk pengembangan profesional di bidang akademis dan penggunaan media sosial untuk pembelajaran profesional. Ini memperluas penelitian untuk menggambarkan komunitas yang terstruktur menggunakan platform media sosial untuk melibatkan fakultas, membangun hubungan, dan mendorong pembelajaran bersama.

Sedangkan Händel et al. (2020) menyelidiki seberapa siap mahasiswa pendidikan tinggi untuk pengajaran jarak jauh darurat karena pandemi COVID-19 dan bagaimana hal ini memengaruhi persepsi sosio-emosional mereka. Analisis mengungkapkan dua kelompok siswa yang berbeda secara signifikan dalam hal kesiapan mereka untuk pembelajaran digital (dalam hal ketersediaan alat teknologi, pengalaman sebelumnya dengan e-learning, dan keterampilan untuk pembelajaran digital). Akhirnya, persepsi sosio-emosional mahasiswa, yaitu emosi yang berhubungan dengan stres (khawatir, ketegangan, kegembiraan, dan kelebihan beban) serta kesepian sosial dan emosional secara signifikan berbeda karena keanggotaan cluster. Oleh karena itu, penelitian ini menunjukkan perlunya dukungan mahasiswa pendidikan tinggi agar berhasil mengatasi tantangan pembelajaran jarak jauh darurat.

\section{Pendidikan Tinggi Jarak Jauh}

Konteks penelitian ini adalah Universitas Terbuka (UT), sebuah perguruan tinggi negeri yang menerapkan sistem pendidikan jarak jauh terluas di Indonesia. Sistem pembelajaran jarak jauh ditandai dengan tidak adanya tatap muka antara guru dan siswa. Ada sarana untuk 
Jurnal Ilmu Komunikasi UHO : Jurnal Penelitian Kajian Ilmu Komunikasi dan Informasi.

Volume 7, No. 1, Januari 2022, hlm 79-91

menjembatani kesenjangan antara mereka dengan memanfaatkan berbagai media dalam proses pembelajaran.

Dalam pendidikan jarak jauh kemungkinan seleksi seringkali sangat terbatas karena alasan keuangan dan lainnya. Kata-kata tercetak dan tertulis di satu sisi dan rekaman audio di sisi lain terkadang menghabiskan kesempatan seleksi. Kombinasi yang cocok dari ini menawarkan pilihan tambahan. Misalnya, mungkin berguna untuk memberikan instruksi yang direkam tentang cara mempelajari bagan dan gambar yang disajikan dalam bentuk cetak, suatu prosedur yang terbukti menguntungkan bagi kelompok sasaran yang memiliki sedikit keterampilan membaca. Namun, dalam kasus lain, pilihan dapat dibuat di antara beberapa media yang disebutkan di atas (Holmberg, 1989).

Jelas bahwa sifat masing-masing media komunikasi memiliki dampak langsung pada tingkat dan kualitas dialog antara pengajar dan peserta didik. Misalnya, sebuah program pendidikan di mana komunikasi antara guru dan peserta didik hanya melalui televisi satu arah, kaset audio, atau buku belajar sendiri, tidak akan memiliki dialog guru-peserta didik hanya karena media ini tidak dapat membawa pesan kembali dari peserta didik ke peserta didik. guru.

\section{Tutorial Online}

Proses pembelajaran di perguruan tinggi jarak jauh di UT menggunakan media berupa tutorial. Tutorial online (TO) merupakan salah satu layanan pembelajaran yang disediakan oleh UT yang diberikan secara gratis, setelah mahasiswa melakukan registrasi. Belajar melalui layanan TO murah dan cepat, karena mengakses email bisa dilakukan di WarposnetWarposnet hampir di setiap kecamatan, bagi mahasiswa yang sudah bekerja dan kantornya memiliki fasilitas Local Area Network (LAN), mahasiswa juga dapat mengakses $e$-mail dari kantor, bagi mahasiswa yang memiliki fasilitas LAN sendiri di rumah dapat mengakses $e$ mail dari tempat tinggalnya dan bagi mahasiswa yang tidak memiliki jaringan LAN atau tidak bekerja dapat mengakses e-mail dari Warposnet -Warposnet di setiap kecamatan terdekat. Biaya akses e-mail relatif murah dan isi pesan yang akan ditanyakan hari itu juga dapat menjangkau UT Center. Belajar di UT secara umum memang memiliki beberapa kendala utama, salah satunya adalah faktor kedisiplinan yang tinggi dalam mengatur waktu belajar. Selain itu, terdapat beberapa kesulitan lain seperti tidak adanya ikatan emosional dengan sesama siswa dan tidak adanya suasana belajar seperti siswa konvensional. 
Jurnal Ilmu Komunikasi UHO : Jurnal Penelitian Kajian Ilmu Komunikasi dan Informasi.

Volume 7, No. 1, Januari 2022, hlm 79-91

\section{Interaksi Komunikasi dalam Pendidikan Jarak Jauh}

Menurut Moore dan Kearsley (2005) menyatakan bahwa pada perguruan tinggi yang menggunakan sistem pembelajaran jarak jauh, masih terdapat interaksi antara mahasiswa dengan staf pengajar atau administrator, sedangkan interaksi tersebut berupa; Interaksi antara siswa dan bahan ajar, interaksi ini yang memungkinkan siswa memperoleh pengetahuan dan fakta dari bahan ajar; Interaksi antara tutor dan siswa yaitu nteraksi yang berperan dalam memelihara atau meningkatkan motivasi siswa, memberikan umpan balik dan dialog antara tutor dan siswa; Interaksi antara siswa dan siswa yaitu interaksi yang memungkinkan siswa untuk saling bertukar informasi, saling belajar dan saling memperdalam pengetahuan yang relevan dengan mata pelajaran yang dipelajari, dan; Interaksi antara tutor dan tutor yaitu interaksi yang terutama ditujukan untuk memperlancar komunikasi antar tutor dalam rangka pendalaman dan pengayaan materi pembelajaran. Interaksi-interaksi tersebut akan terwujud dengan baik apabila didukung oleh pemanfaatan media sosial.

\section{METODE PENELITIAN}

Penelitian ini menggunakan pendekatan kuantitatif dimana data dilakukan dengan metode survei dengan menggunakan instrumen kuesioner. Populasi penelitian ini adalah seluruh mahasiswa yang telah mendaftar semester ganjil dan genap tahun 2021 pada Program Studi Ilmu Komunikasi. Teknik pengumpulan data dilakukan melalui online menggunakan Google form via WhatsApp Group. Untuk memperdalam kondisi responden, penelitian ini juga mewawancarai beberapa responden untuk melengkapi data kuantitatif melalui pertemuan offline secara terbatas menggunakan Focus Group Discussion (FGD) dengan tetap menjalankan dan menjaga prosedur kesehatan karena masih dalam masa Pandemi Covid-19. Adapun tempat FGD dilakukan di Kantor Wilayah Yogyakarta dan Bogor. Sampel diambil secara purposive sebanyak 118 responden.

\section{HASIL DAN PEMBAHASAN}

\section{Data Demografis}

Diagram 1(a) menunjukkan bahwa karakteristik responden berdasarkan jenis kelamin lebih banyak perempuan daripada laki-laki, hal ini mencerminkan bahwa perempuan sudah memiliki kesadaran untuk melanjutkan ke perguruan tinggi atau melanjutkan studi ke jenjang perguruan tinggi. 
Jurnal Ilmu Komunikasi UHO : Jurnal Penelitian Kajian Ilmu Komunikasi dan Informasi.

Volume 7, No. 1, Januari 2022, hlm 79-91

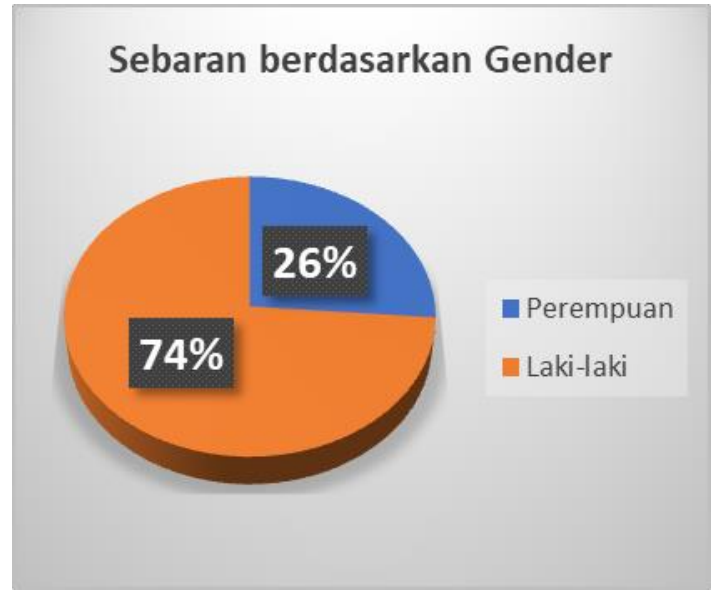

(a)

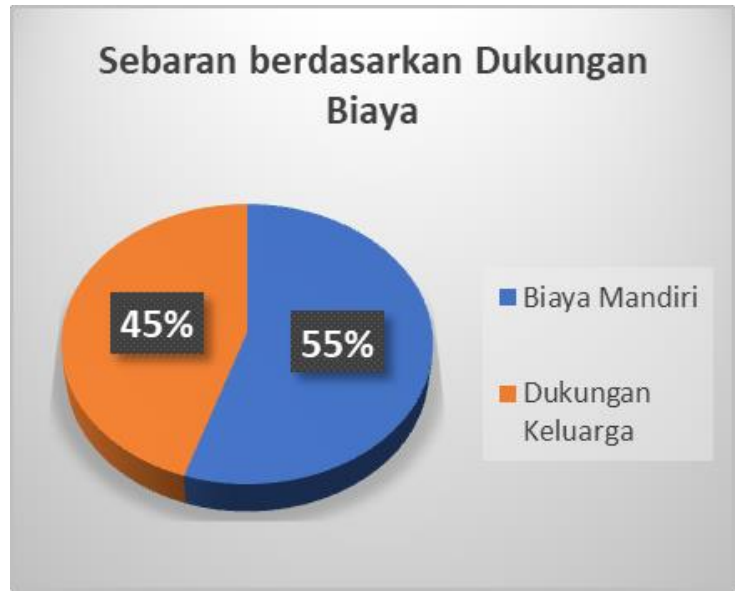

(b)

Sumber: Hasil penelitian, 2021

\section{Diagram 1. Sebaran berdasarkan (a) jenis kelamin dan (b) dukungan biaya kuliah}

Selanjutnya untuk mengetahui sebaran responden berdasarkan dukungan biaya pendidikannya. Diagram 2 menunjukkan bahwa responden yang mendapatkan dukungan keluarga untuk biaya sekolah hampir $45 \%$ dan mereka yang mandiri mendapatkan biaya sekolah yang lebih tinggi. Hal ini menginformasikan bahwa lebih dari separuh responden mandiri dalam penelitiannya sendiri.

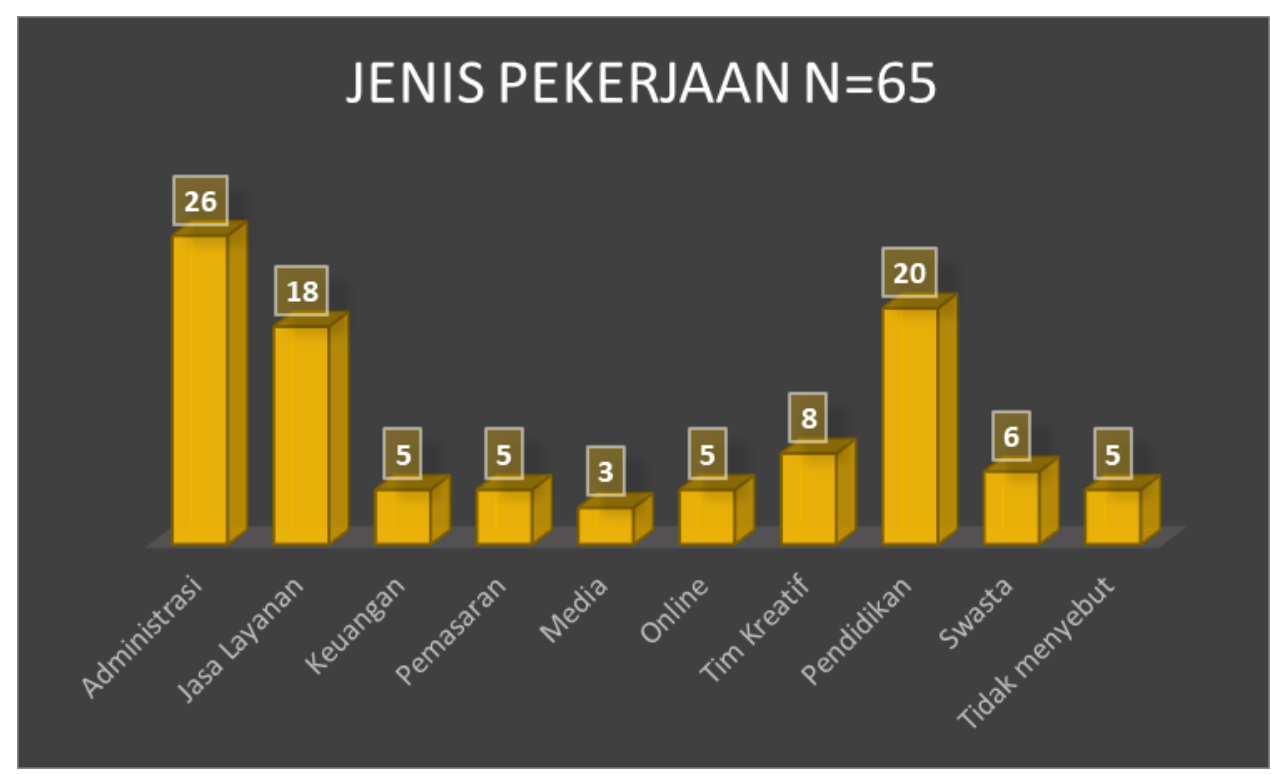

Sumber: Hasil penelitian, 2021

Diagram 2. Sebaran responden berdasarkan jenis pekerjaan

Mahasiswa Universitas Terbuka yang menggunakan sistem pendidikan jarak jauh tidak memiliki batasan usia, artinya lebih dari separuh responden di lapangan telah bekerja secara 
Jurnal Ilmu Komunikasi UHO : Jurnal Penelitian Kajian Ilmu Komunikasi dan Informasi.

Volume 7, No. 1, Januari 2022, hlm 79-91

profesional sebelum mengikuti program tersebut. Responden survei memiliki tiga jenis pekerjaan utama: pegawai swasta, sektor pendidikan dan jasa, serta pekerja di industri kreatif (tim kreatif, pekerja media, pekerja media online, pekerja keuangan, dan pemasaran). Karena sebagian besar studi sebelumnya telah gagal, informasi ini menarik (Diagram 2).

\section{Penggunaan Media Sosial}

Ada tiga platform media sosial utama yang digunakan responden untuk mendukung dan melengkapi informasi terkait pembelajaran siswa yaitu WhatsApp, Facebook, dan Instagram. Ditemukan beberapa WhatsApp Groups (WAG) kelompok belajar untuk sarana informasi dan komunikasi terkait proses pembelajaran, termasuk Komunitas Belajar Mahasiswa

Tabel 1. Sebaran responden berdasarkan penggunaan media sosial

\begin{tabular}{lcccccc}
\hline \multicolumn{1}{c}{ Penggunaan Sosial Media } & Instagram & WhatsApp & Line & Twitter & Facebook & Telegram \\
\hline Komunikasi \& sosialisasi & 3 & 114 & 1 & 0 & 0 & 0 \\
Mengekspresikan diri & 76 & 33 & 0 & 4 & 5 & 0 \\
Belajar \& kepentingan kampus & 14 & 94 & 1 & 0 & 2 & 7 \\
Hiburan atau hobi & 79 & 9 & 1 & 6 & 14 & 9 \\
\hline
\end{tabular}

Sumber: Hasil penelitian, 2021

Program Komunikasi (KUBIK) yang memiliki kegiatan diskusi di antaranya. Diskusi tersebut meliputi bagaimana menganalisis tugas-tugas yang diberikan Tugas Akhir Program (FAP), salah satu Program Studi Ilmu Komunikasi, diskusi dengan tutor mereka dalam tutorial FAP mereka, mereka membahas bagaimana menentukan judul atau tema sebuah karya ilmiah, merumuskan, dan menganalisis dia.

Sementara itu menurut hasil penelitian Akçayır (2017) mengungkapkan bahwa siswa aktif menggunakan media sosial untuk tujuan yang berbeda. Para peserta juga menunjukkan persepsi positif tentang penggunaan SNS untuk tujuan pendidikan. Di antara harapan terbesar adalah bahwa instruktur akan berbagi materi menggunakan SNS. Ketika harapan umum siswa diperiksa, hasil yang sangat berbeda diperoleh. Kekhawatiran terbesar dari siswa adalah bahwa posting pribadi mereka dapat dilihat oleh instruktur mereka. 
Jurnal Ilmu Komunikasi UHO : Jurnal Penelitian Kajian Ilmu Komunikasi dan Informasi.

Volume 7, No. 1, Januari 2022, hlm 79-91

Informasi, seperti memeriksa jadwal penting tentang kapan siswa mendaftar untuk kelas, memulai tutorial online dan web, mengikuti ujian akhir, dan mendapatkan informasi tentang akademik siswa dan kegiatan pengabdian masyarakat adalah semua hal yang siswa gunakan setiap hari di Facebook. Selain ekspresi diri melalui hobi seperti berjualan kain batik, pakaian, kue, dan kue kering lainnya, mahasiswa juga menggunakan Instagram untuk emposting kegiatan akademik dan konten lain yang mereka geluti.

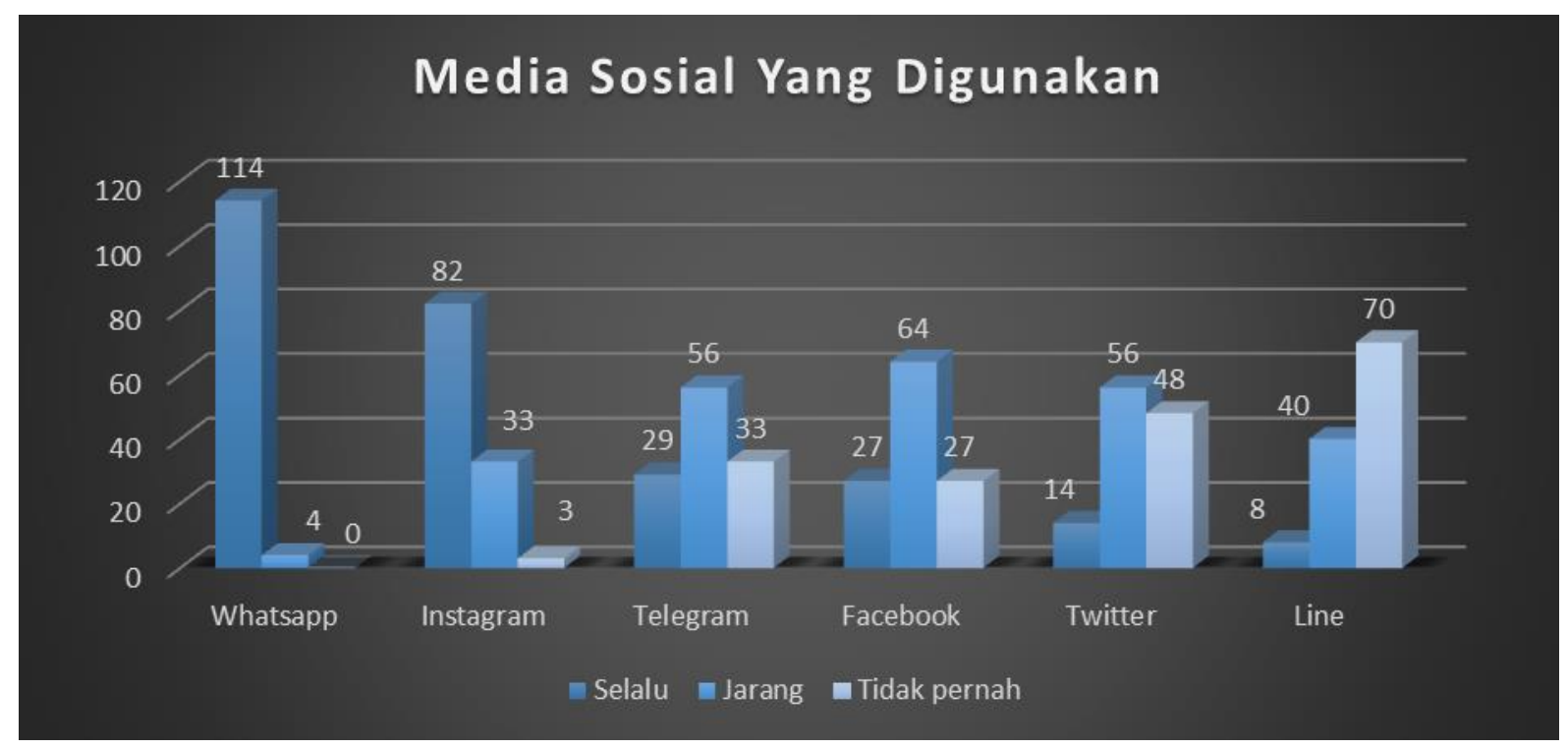

Sumber: Hasil penelitian, 2021

Diagram 5. Sebaran responden berdasarkan Media Sosial yang digunakan

Menurut frekuensi siswa menggunakan media sosial, dapat disimpulkan bahwa WhatsApp adalah yang paling populer, yang dapat dimengerti mengingat fleksibilitas dan kemudahan penggunaan aplikasi, serta fakta bahwa itu asli dan dapat mengirim dan menerima pesan di waktu yang sama. Siswa di WAG KUBIK berasal dari seluruh Indonesia, termasuk pantai barat, Sumatera, dan pulau Jawa. Mereka juga memiliki beberapa mahasiswa dari Indonesia Timur, seperti Nusa Tenggara Timur dan sekitarnya, di grup WAG yang berasal dari wilayah Indonesia Tengah. Sementara Instagram dan Telegram berada di urutan kedua dan ketiga. Siswa menyukai tiga platform media sosial karena mudah digunakan dan efektif.

Hasil penelitian in didukung oleh penelitian Starcic, Barrow, Zajc, and Lebenicnik (2017) prediktor yang mempengaruhi utama adalah keyakinan siswa bahwa SNS mendukung kontrol karir dan keterlibatan siswa dalam proses pendidikan melalui jaringan untuk belajar. 
Jurnal Ilmu Komunikasi UHO : Jurnal Penelitian Kajian Ilmu Komunikasi dan Informasi.

Volume 7, No. 1, Januari 2022, hlm 79-91

\section{SIMPULAN}

Secara demografi, Prodi Ilmu Komunikasi mayoritas adalah mahasiswi yang berjumlah 73 persen dari total responden. Sedangkan mahasiswa yang menghidupi diri sendiri 55 persen, yang sebagian besar bekerja di karyawan administrasi 26 persen, pendidikan 20 persen dan jasa layanan 18 persen, sedangkan kelompok pekerjaan media 16 persen, kelompok bisnis 10 persen.

Media sosial sangat penting bagi kehidupan mahasiswa (1) WhatsApp adalah yang paling populer di kalangan mahasiswa media sosial ini digunakan sebagai alat komunikasi dengan teman, untuk belajar diskusi dengan teman kampus, dan untuk mengekspresikan diri; (2) Instagram umumnya digunakan untuk hiburan dan melakukan hobi mereka; (3) Facebook umumnya digunakan untuk hiburan, hobi, ekspresi diri, dan belajar tutorial singkat informal.

Untuk penelitian selanjutnya, disarankan untuk meneliti penggunaan media untuk membantu atau mendukung kegiatan belajar mereka sehingga diharapkan dapat bermanfaat bagi institusi dan juga siswa. 
Jurnal Ilmu Komunikasi UHO : Jurnal Penelitian Kajian Ilmu Komunikasi dan Informasi.

Volume 7, No. 1, Januari 2022, hlm 79-91

\section{DAFTAR PUSTAKA}

Akçayır, M. (2017). What do students think about SNSs in education? University students' perceptions, expectations and concerns regarding educational uses of SNSs. Australasian Journal of Educational Technology, 33(5).

Alvarez-Garcia, C., Alvarez-Nieto, C., Kelsey, J., Carter, R., Sanz-Martos, S., \& Lopez-Medina, I. M. (2019). Effectiveness of the e-NurSus Children Intervention in the Training of Nursing Students. Int J Environ Res Public Health, 16(21). doi:10.3390/ijerph16214288

Angeline, M. X. (2019). Skills Of Using Internet And Computer Communication Network Among Library Professionals Working In Selected Arts And Science Colleges: Affiliated To Bharathidasan University Library Philosophy and Practice (e-journal). (2265).

Bedford, L. (2019). Using Social Media as a Platform for a Virtual Professional Learning Community. Online Learning, 23(3). doi:10.24059/olj.v23i3.1538

Berg, S., Forest, J., \& Stenseng, F. (2020). When Passion Does Not Change, but Emotions Do: Testing a Social Media Intervention Related to Exercise Activity Engagement. Front Psychol, 11, 71. doi:10.3389/fpsyg.2020.00071

Boursier, V., Gioia, F., Musetti, A., \& Schimmenti, A. (2020). Facing Loneliness and Anxiety During the COVID-19 Isolation: The Role of Excessive Social Media Use in a Sample of Italian Adults. Front Psychiatry, 11, 586222. doi:10.3389/fpsyt.2020.586222

Gupta, S., \& Bashir, L. (2018). Social Networking Usage Questionnaire: Development and Validation In An Indian Higher Education Context. Turkish Online Journal of Distance EducationTOJDE 19(4).

Händel, M., Stephan, M., Gläser-Zikuda, M., Kopp, B., Bedenlier, S., \& Ziegler, A. (2020). Digital readiness and its effects on higher education students' socio-emotional perceptions in the context of the COVID-19 pandemic. Journal of Research on Technology in Education, 1-13. doi:10.1080/15391523.2020.1846147

Holmberg, B. (1989). Theory and Practice of Distance Education. London: Rotledge.

Icha, O., \& Edwin, A. (2016). Effectiveness of Social Media Networks as a Strategic Tool for Organizational Marketing Management Journal of Internet Banking and Commerce, 21(S2).

Kwaghga, B., Okike, O. I., Benedict , \& Ramatu, A. T. (2019). Social Media Use and its Influence on Academic Performance of Postgraduate Students of Benue State University, Makurd. Library Philosophy and Practice( 3056), 13.

Li, X., \& Liu, Q. (2020). Social Media Use, eHealth Literacy, Disease Knowledge, and Preventive Behaviors in the COVID-19 Pandemic: Cross-Sectional Study on Chinese Netizens. J Med Internet Res, 22(10), e19684. doi:10.2196/19684

Radwan, E., Radwan, A., \& Radwan, W. (2020). The role of social media in spreading panic among primary and secondary school students during the COVID-19 pandemic: An online questionnaire study from the Gaza Strip, Palestine. Heliyon, 6(12), e05807. doi:10.1016/j.heliyon.2020.e05807 
Jurnal Ilmu Komunikasi UHO : Jurnal Penelitian Kajian Ilmu Komunikasi dan Informasi.

Volume 7, No. 1, Januari 2022, hlm 79-91

Starcic, A. I., Barrow, M., Zajc, M., \& Lebenicnik, M. (2017). Students' Attitudes on Social Network Sites and their Actual Use for Career Management Competences and Professional Identity Development. iJET 12(5). doi:10.3991/ijet.v12i05.6778 